\title{
Ruinopolis: Post-Imperial Theory and Learning from Las Vegas
}

\author{
JULIA HELL and GEORGE STEINMETZ
}

\begin{abstract}
This essay foregrounds a dimension of Las Vegas that other authors only touch on in passing: its connections to empire. The authors propose a post-imperial analysis of the city based on a reconstruction of its history and a reading of the traces of this history in the city's architecture and its self-presentation in American popular culture. This analysis of Las Vegas as ruinopolis draws attention to the ruin sites of the city and its hinterland, reading them through the lens of empire. We work out the imperial territoriality of Las Vegas, including the derelict space of the Las Vegas Paiute Indian Colony, the 'Pentagon Desert' around the city with its so-called 'national sacrifice zone', and the Strip, with Caesars Palace. We conclude with a post-imperial reading of Venturi, Scott Brown and Izenour's canonical Learning from Las Vegas and of the ruin signs of the Neon Boneyard.
\end{abstract}

\section{Introduction}

Friedrich Ratzel, the founder of political geography, was one of the first theorists of the distinctive properties of modern empires. Stripped of their Social Darwinist underpinnings, Ratzel's ideas about imperial geopolitics and capitalism provide a starting point for the analysis of Las Vegas as a ruinopolis, a desert metropolis signifying the waning of US imperialism. In 1876 Ratzel published Städte- und Culturbilder aus Nordamerika (Sketches of Urban and Cultural Life in North America). Ratzel based the book on his three-year journey through the United States, Mexico and Cuba; it was the first example of what was to become Ratzel's distinctive approach to the study of politics, culture and place. Most interesting in light of the current interest in modern ruins and the rise of an interdisciplinary field of ruinology (Hell and Schoenle, 2010) in the UK and the US is the fact that Ratzel concluded his book on America with a chapter entitled 'Ruins'. According to Ratzel, America was already 'aging fast', with 'cultural ruins along the Pacific Railroad', in the 'mining areas' and in the southern states due to the civil war. He continued:

That nice little saying of Goethe which talks about a lack of ruins [in America] . . . no longer applies; rather, it confuses many people's thinking. One has to keep in mind that even if

For comments on earlier drafts of this essay we would like to thank Daryl Martin, Neil Brenner, Martha Knack and three anonymous IJURR reviewers. For help with sources and images we would like to thank Susan Scanlon (personal assistant to Denise Scott Brown), Nic Heckner (University of Michigan, German Studies), Pamela Quick (MIT Press), Kelli Luchs (UNLV Special Collections), Liz Moore (Nevada State Archives), Mitch Ison (Nevada State Library), Chris Petersen (Oregon State Special Collections and Archives Research Center), Ginny Poehling (Las Vegas News Bureau), Jungwon Yang (University of Michigan, Clark Library) and Joe Schoenmann (Las Vegas Sun). 
civilization here is young in years, it has lived all the more rapidly ... Many people think that the process of development has gone on too quickly and has prematurely stamped all of the character traits of Europe's younger sibling in ways that do not seem very healthy ... To be sure, our castle and monastery ruins are of a somewhat different variety than the ruins you find here. The former are the funerary monuments of an era that has completely vanished ... How different these witnesses of a swift life! These don't comfort us ... for on the whole they are clearly destined to a decline that will occur just as rapidly as the lifestyle that created them (1876: 248-9; 1988 [1876]: 285-6, translation modified)

Ratzel soon turned his attention to the geopolitics of empire (Steinmetz, 2012). In his foundational Political Geography, Ratzel (1923 [1897]) analyzed frontier zones within Europe as 'ruin belts'. Like America, Europe too had modern ruins, resulting mainly from the incessant pressures of political expansion in all directions. Ratzel started from the premise that 'every living organism required a certain amount of territory from which to draw sustenance', and he labeled this territory 'the respective Lebensraum, or living space, of the organism in question' (Bassin, 2003: 16). As a state's population grows, according to Ratzel (1897: 297), it requires a larger Lebensraum; and 'as more and more states grow up, the nearer do they edge together': they then begin to 'act and react upon one another'. There is thus a natural tendency for states to engage in conquest and to expand: 'in the long run, nature does not let a Volk remain immobile, it has to move forward or backward' (Ratzel, 1882: 116). Since the earth's surface was considered to be completely occupied by states by the end of the nineteenth century, these expansionary pressures led not only to conquest and annexation but to the growth of ruin belts along the lines of friction between states.

Focusing on the concept of Raumbewältigung, or mastery of space, Ratzel returned again and again to the Roman empire. ${ }^{1}$ Ratzel thought that the Roman empire taught the world how to build and maintain vast empires over large stretches of land. According to Ratzel, Rome endured, and so do all empires that have a strong Volk at their core. Ratzel emphasized the duration and stability of post-Roman empires. Rome existed for centuries, and the Roman lesson argued against the popular idea of the 'transience of world empires' (ibid.: 160). For this theorist of empire writing at the height of German imperialism, imperial duration was a crucial concern. This topic not only informs Ratzel's discussion of the different forms of empire but also underlies his categorization of different kinds of ruins. Again, the ruins of imperial Rome stand out for Ratzel, and they are as enduring as Rome's empire itself. If we were to map the world's distribution of ruins, he says, we would find 'countries rich in ruins' exactly in those places where the Romans once ruled (ibid.: 515).

Ratzel's logic of ruin is thus specifically imperial, deriving from empire's expansionary impetus. Although these geo-imperial dynamics are of course usually intertwined with the logics of capitalism, they cannot be reduced to the latter. However, capitalism is also part of Ratzel's picture. What he observes in his American travelogue is how a vast continent is appropriated and commodified according to a capitalist logic. That is, the production of everything from the most mundane objects to houses and entire cities is oriented towards profit maximization and short-term use. Use values that were traditionally produced for consumption by their producers and that were understood as aging naturally along with their producers now become commodities designed and destined to quickly become rubbish — ruined sheds, not castles.

This is the logic prominent in much of the literature on present-day Detroit, and it also informs most of the literature on Las Vegas, the frontier city of capitalist excess. What these two iconic American cities are said to have in common is their boom-and-bust pattern of development. The initial expansion of both cities is directly tied to the prosperous conditions of postwar Fordism, although Las Vegas underwent a second 
boom period in the decade before 2008 while Detroit continued to decline. In the wake of the recession, however, an image of Las Vegas has emerged that portrays it as the "new Detroit' - the new American city in ruins.

What do these recent discussions of Las Vegas highlight? They tend to focus on the financial problems of new construction projects involving 'signature architects' along the Boulevard, such as CityCenter (Huber and Stern, 2010: 198). CityCenter almost shared the fate of the Fontainebleau Resort, an unfinished US \$2.9 billion dollar casino-resort that is the 'largest commercial construction project to go bankrupt in the country' (Finnegan, 2011). The legendary Stardust Casino was demolished by its owners 'in a large fireworks enhanced ceremony with the plans of constructing [a] high luxury megaresort in Las Vegas named Echelon Place'. After 'ground was broken', the economic crisis brought construction to a halt 'with no planned day for it to resume' (LasVegasMichael, 2012). The Harmon Hotel tower was part of another multi-billion dollar complex designed by Norman Foster. It now stands as an uncompleted 26-storey stump that has been turned into a structure advertising an adjacent shopping center. Beyond the Strip there is an ocean of stalled construction sites and entire subdivisions in foreclosure (Segall, 2012). And while the 'death of the construction industry has claimed thousands of jobs' (Garcia, 2011), a new form of entertainment has emerged in Las Vegas where tourists can pay to drive heavy excavators and bulldozers around a disused construction site.

Thus Las Vegas has started to be described in terms previously reserved for older rustbelt cities like Detroit. Before 2008 Las Vegas was often compared to Detroit during its mid-twentieth-century era of Fordist prosperity. Writers who called Las Vegas the 'last Detroit' were referring at that time not to the Detroit of urban ruins and population loss but to the city 'that offered the working class a good wage, the opportunity to buy a home, and the hope of entering the middle class' (Rothman 2003: 63; see also Rothman, 2002: 63-88; Huber and Stern, 2010: 163). At the same time that Detroit was the center of mass production in the US, Las Vegas was the center of industrialized mass consumption. ${ }^{2}$ Las Vegas currently has record-breaking levels of unemployment, foreclosures and homelessness, plus one of the notorious populations of 'tunnel people' — people living in storm drains beneath the city (Gottdiener et al., 1999: 211; O'Brien, 2007; 2010; Borchard, 2011; Garrahan, 2011). Las Vegas is now also said to have the highest suicide rate in the US. In August 2012, mannequins were seen dangling from nooses beneath billboards in Las Vegas with signs reading 'Dying for Work' and 'hope you're happy Wall St' (OccupyLV, 2012). As Gold (2011) writes, 'Las Vegas looks a lot like the new Detroit'.

Not surprisingly, one of the local bloggers discussed these developments under the heading of 'The Roman Ruins of Las Vegas' (LasVegasMichael, 2012). By 2012 the framing of these recession remnants as imperial ruins was available to him because of the explosion of discussion of the United States as an empire during the last decade. One of the more infamous statements was Karl Rove's pronouncement in 2004 that 'we're an empire now, and when we act, we create our own reality' (quoted in Suskind, 2004: 51). Predictably, part of this whole discourse was the question of whether the US is an intact empire or an empire in decline. With this question, we saw the re-emergence of the trope of the imperial ruin gazer (Hell, 2008; 2009; 2010). These discussions about the possible end of the American empire intensified with the economic crisis, reaching fever pitch during the presidential campaign of 2012.

In 2006, an exhibition in New York entitled Course of Empire displayed Thomas Cole's cycle of paintings 'The Course of Empire', which ends with the depiction of a former metropolis in ruins, alongside Ed Ruscha's deadpan paintings of industrial buildings (Hell, 2010: 175-6). Ruscha's suite of black-and-white canvasses juxtaposed

2 As regulation theorists have argued, Fordism as a mode of regulation was based on an articulation of mass consumption and mass production; see Aglietta (1979). 


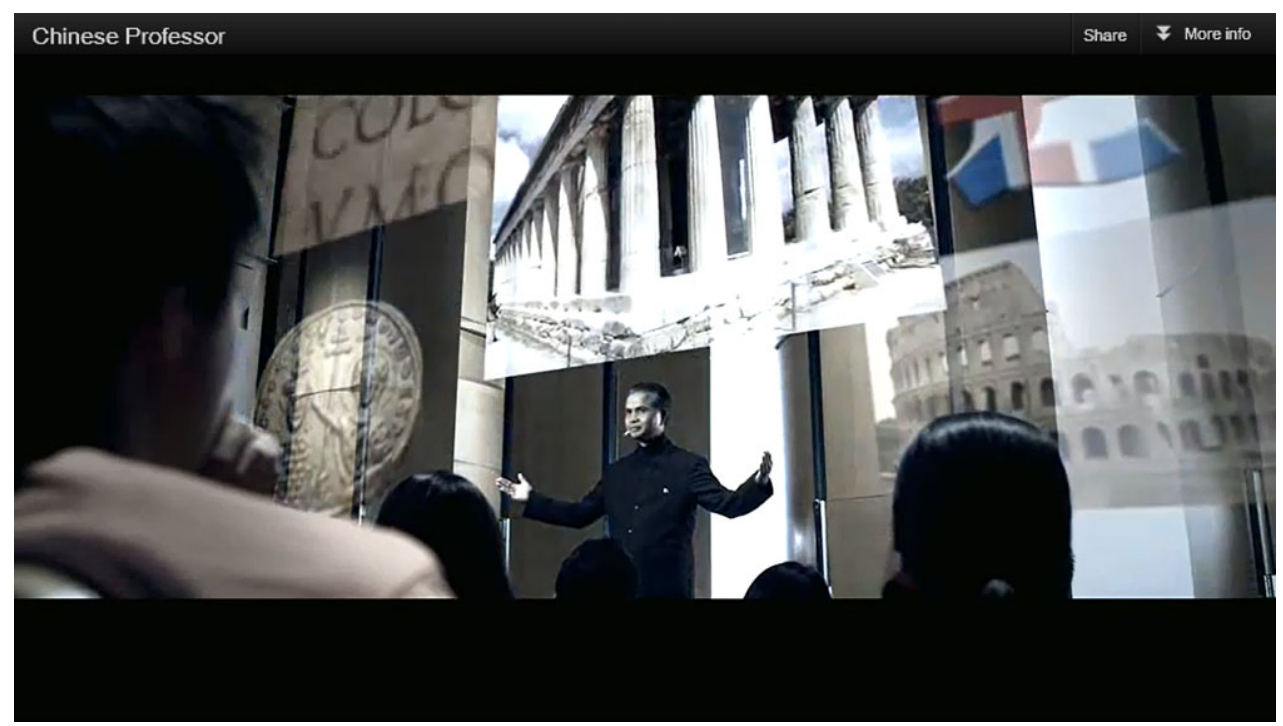

Figure 1 Still from Chinese Professor advertisement (Citizens against Government Waste, 2010)

two versions of the same buildings, the second series exhibiting subtle signs of decay. One of the buildings' facades in the new series is 'cluttered with Chinese characters' (NYFA, n.d.). By displaying his paintings together with Cole's, Ruscha linked imperial decline to Fordist decline, creating a constellation heavy with sadness, a kind of memento mori of empire. 'I wish time would stand still' was Ruscha's comment (ibid.).

This discourse about the end of the American empire and this trope of imperial ruin gazing also emerged during the recent presidential campaign, when a group called Citizens against Government Waste ran an advertisement on television and in multiplex theaters across America. Entering a large lecture hall, a Chinese professor's first sentence is: 'Why do great nations fail?'. The next shot shows two of the classic Western empires' emblematic images: the Acropolis and the Coliseum (Figure 1). The lecturer then compares the decline of the US to that of the ancient Greeks, the Roman empire and the British empire.

Taking as our starting point this resurgence of the trope of the imperial ruin gazer, we propose to analyze Las Vegas as an imperial city. This approach reconstructs the city's imperial history; we then uncover the traces of this imperial dimension in the fabric and architecture of the city and also in the theoretical reflections about this architecture. Our analysis is specifically 'post-imperial' in the same sense that postcolonial analysis was first and foremost a perspective on the colonial era that paid special attention to colonialism's cultural and representational dimensions. Las Vegas has been deeply shaped by empire and has been consistently represented and understood as imperial. Post-imperial analysis is, for us, as much about rethinking the representations of the city as it is about reconstructing the city's history. Or, put differently, the reconstruction of the city's imperial history goes hand in hand with the analysis of the traces of imperial history in the city's landscape and architecture.

Post-imperial analysis, as we define it, and as applied to the specific case of Las Vegas, pays attention to the cultural resonances of three different aspects of empire: (1) formal colonialism, which in the present case is directed above all at Native Americans; (2) post-slavery, represented in Las Vegas by the labor of the African Americans who built the modern city; (3) informal imperialism, represented by the United States as a declining geopolitical military hegemon. A combined focus on colonialism and imperialism is important for the analysis of Las Vegas and in understanding the United 
States more generally. The word imperial, as used here, encompasses empires ancient and modern, Western and non-Western, continental and informal, colonial and non-colonial. Empires in the most general sense are like states, but differ in two particular ways - their inherent expansiveness and the asymmetrical power relations they install between the core state and the conquered peripheries. Colonialism is a subtype of empire in which a conquering power retains direct control of a conquered polity and defines its native inhabitants as inherently inferior and incapable of self-rule. ${ }^{3}$

A century after Ratzel explored American ruins in the west and reflected on empires and their ruins, another European traveler asked in 1986: is this 'the end of US power?'. The 1950s, Baudrillard (2010 [1986]: 117) wrote, nostalgically represent to Americans 'the ecstasy of power'. Today there is widespread agreement across the political spectrum that the American empire is waning. Immanuel Wallerstein (2003) and world system theorists have been predicting the end of US hegemony since the 1980s (Bergesen and Sahoo, 1985), analyzing its terminal crisis as involving excessive militarization (see also Kennedy, 1987). The recent Global Trends Report by the National Intelligence Council (2012: ii) anticipates that by 2030 there 'will not be any hegemonic power' but rather a 'multipolar world' of 'networks and coalitions'.

Our analysis is thus also post-imperial because we are poised at the cusp of a transition away from imperial hegemony. The end of the American empire should affect our analysis in ways similar to the impact of decolonization, which brought certain elements of colonial rule into sharper relief. The analysis of Las Vegas as imperial city will uncover various imperial sites: inside the city, the imperially themed casinos, the neon-sign Boneyard and the Paiute Indian Colony, until recently a barely visible derelict space; outside the city, the ruins of the atomic test sites, a drone warfare program and ancient Indian lands.

Among the imperially themed casinos, we will focus on Caesars Palace in its two incarnations: one of them early postmodern, the other late postmodern; one of them a serious parody of imperial Rome, the other a dead serious parody. Caesars Palace figures centrally in Venturi, Scott Brown and Izenour's Learning from Las Vegas (LLV). We will read Caesars Palace as imperial and $L L V$ as an imperial manifesto for a Fordist empire, published in 1972, just before that Fordist empire began to crumble. Of course cities like texts have multiple meanings. Pursuing this particular imperial logic, we are not, for instance, exploring how Las Vegas' architectural mimicry relates to its originals or, put differently, whether tourists are being duped into thinking they are in Italy. ${ }^{4}$ In contrast, we argue that one of the messages of Caesars Palace is: you are in the United States, in the heart of a post-Roman empire. Second, Caesars Palace is a place where the populist representation of a self-confident empire has changed into the brutalist forms of a hyper-militarized empire in crisis.

\section{Reconstructing imperial history and culture: from Paiute Indians to predator drones}

What does United States history look like from the standpoint of empire? The US has engaged in imperial policies since its beginnings as an independent nation. The country's founders engaged in discussions of whether it should be a republic or an empire. The

3 For definitions of empire see Steinmetz (2005).

4 Like the literature on 'post-tourism', for instance, our post-imperial analysis finds Las Vegas to be a significant site. We differ, however, in reading Las Vegas not from the perspective of authentic or inauthentic experience. The analysis of Las Vegas ranges from the traditional Adornian critique of the culture industry to critics inspired by Baudrillard, who sees Las Vegas as a place that "killed off all negotiation of meaning' (Minca, 2005: 199). 
Monroe Doctrine codified a politics of non-colonial hegemony over the entire Western hemisphere (Schmitt, 1950) and during the mid-twentieth century the US became a global hegemon, with a worldwide network of military bases (Lutz, 2009; Johnson, 2010) and ever-improving military technology. Since the demise of the USSR, American military spending has grown to such an extent that it presently exceeds the combined military expenditures of the next 40 highest-spending countries (Stockholm International Peace Research Institute, 2012). But this extraordinary military expansion does not necessarily contradict the diagnosis of the American decline. World systems theory argues that the end phase of a hegemonic cycle, in which the hegemonic state declines in terms of its comparative economic paramountcy, is often accompanied by a hypertrophic expansion of that state's imperial extensions and apparatuses as it tries to fend off challenging would-be hegemons.

The US has also been a specifically colonial empire since the middle of the nineteenth century and this continues to the present day. There are two dimensions of American colonialism (not to be confused with 'colonization'): an internal colonialism directed at Native Americans and formal colonial rule over foreign polities. Relations between the federal government and Native Americans under British rule and in the decades after independence were not fully colonial, even if they involved warfare, massacre and land expropriation. Indians were treated as external threats or potential allies rather than as internal colonized 'Others' (Calloway, 2006). The US Indian Office was part of the War Department until 1849, at which point it was transferred to the Interior Department (Rockwell, 2010: 247). Between the 1840s and the 1860s, Indian policy came to be centered on the institution of the reservation (Trennert, 1975). Every Indian was now to be associated with a tribe, each tribe was to be assigned to a reservation and each reservation was to be supervised by Bureau of Indian Affairs agents, performing roughly the same role as district commissioners in British Africa or commandants du cercle in French colonies.

As the United States was building up this formal internal colonial apparatus to govern Native Americans, it also began asserting sovereignty over overseas colonies. This started with Hawaii and culminated in the takeover of Puerto Rico, the Philippines and smaller Pacific colonies at the end of the nineteenth century. After 1945 the US bolstered European colonial empires, underwriting the costs of the British empire for several years, stationing troops in French North Africa, and offering military assistance to the French in Indochina. The US only began to directly oppose European colonialism as the Cold War intensified (Louis and Robinson, 1994: 468-9). These American imperial ventures have profoundly shaped Las Vegas and its surrounding area.

\section{Imperial territoriality: the Paiute Colony and reservation}

When analyzing colonial cities (King, 1976; Osterhammel, 2009: 412-32) or imperial metropoles (Driver and Gilbert, 1999), the spatial scope of analysis needs to be extended to these cities' militarized hinterlands. J.A. Hobson (1965: 151) emphasized the connection between the colonial empire and London's hinterland in Imperialism, writing that if the sources of the incomes expended in the Home Counties and other large districts of Southern Britain be traced to their sources, it would be found that they were in large measure wrung from the enforced toil of vast multitudes of black, brown, or yellow natives, by arts not differing essentially from those which supported in idleness and luxury imperial Rome'. A post-imperial approach to the problem of urban imperial territoriality must attend to both the city and the region.

As Kuletz (1998: 126, 135) writes of southern Nevada, 'the ancient Indian pathways ... that organize the space of this region by way of Indian occupation and movement lie beneath the surface of other constructions of space', and these layered political boundaries 'make certain aspects of the landscape visible' and others invisible. What is 
unique to Las Vegas is the existence of the so-called Indian Colony inside the city, a derelict space established in 1911, and since the 1980s, the existence of a larger reservation on the city's outskirts. For over a century, the Las Vegas Indian Colony has been located at the northern edge of the city, just one mile from Fremont Street, the heart of Las Vegas' original gambling district. The reservation headquarters building contrasted starkly with the opulence of the casino district (see Knack, 2001: 264). Until the mid-1960s, the Colony was 'little more than a camp with homes arranged irregularly, no roads, inadequate water supply, and no utilities of any kind' (Inter-Tribal Council of Nevada, 1976: 121). In the words of two tribal leaders, 'the reservation was a sore spot — just a place to live' (Anderson and Mike, 1974: 20). The tribe was 'literally living in cardboard shacks' (United States Senate, 1983: 27).

How did this space come into existence? Las Vegas Springs and the surrounding regions were inhabited by the Southern Paiute when the area was first explored by Spanish missionaries and traders, starting in 1776 (Inter-Tribal Council of Nevada, 1976). Spain 'mapped Paiute land as part of its colonial empire', but neither Spain nor Mexico asserted sovereignty over the Paiutes or settled the region (Knack, 2001: 33, 47). Non-Indian Americans had been visiting the area regularly by the time the territory was ceded to the United States in 1848 (Alley, 1977: 4). John C. Frémont's expedition for the US Army's Corps of Topographical Engineers in the early 1840s inaugurated the 'systematic mapping' of the region that included Las Vegas (Land and Land, 2004: 12).

The violence of initial contact (Inter-Tribal Council of Nevada, 1976: 45; Knack, 2001: 43) gradually came to end with the Mormon occupation of Utah and efforts to bring the Paiute under Mormon political and religious control (Reeve, 2006). In 1855 the Mormons sent missionaries to the Las Vegas Paiute and built a fort which later became the Las Vegas Ranch (Knack, 2001: 63). Two years later the Mormons retreated from Las Vegas in the face of Paiute resistance.

Plans for a formal Paiute reservation in Las Vegas at the site of the old Mormon fort were mooted within the Bureau of Indian Affairs as early as 1870 . The possibility of creating a reservation arose in 1911, when Helen J. Stewart sold 10 acres of her land to the US government for the exclusive use of the Las Vegas Paiute. The Las Vegas 'Indian Colony', as it has since been known, became one of nine Paiute reservations in the southwestern US (ibid.: 148, 154).

Indian reservations in Nevada differed from the standard US pattern insofar as they were often located close to white settlements in order to make the Paiute available as 'a cheap labor supply', to quote from a 1910 Bureau of Indian Affairs inspector's plan (see ibid.: 135). Las Vegas was one of the few towns in the United States with its own kraal of indigenous laborers, a miniature Soweto with Paiutes working as miners, housekeepers and cowboys (Alley, 1977: 8). After the second world war, the Las Vegas Paiute escaped subjection to the so-called Termination policies which ended tribal affiliation and abolished protected trust land for more than 100 Indian tribes (Knack, 2001: 230, 264-5). The Las Vegas Indian Colony had been headed by an informal 'chief' since the early twentieth century, but during the 1960s it adopted a formal binding constitution, making it 'a state within a state' (Anderson and Mike, 1974: 20). ${ }^{5}$

In 1968, the Southern Paiute received a settlement from the Indian Claims Commission, and the Las Vegas Indian Colony made a few improvements. By 1983 it comprised a housing project and a cemetery, a smoke shop and its own 'judicial system, law enforcement, adult education, construction company, and community center' (United States Senate, 1983: 20). In 1983 the US government authorized a new reservation of 3,800 acres for the Las Vegas Paiute located just outside city limits. Today the Indian Colony is still a federally recognized 'Indian Tribal Entity' with a small but vibrant economic presence in the city (Federal Register, 2012). There are more than

5 The Las Vegas Indian Colony currently has its own police chief; see Burbank (1991) and LasVegas Paiute Tribe (2013). 
30,000 American Indians living in Las Vegas Valley, though only about 54 adults currently live on the urban reservation (Hansel, 2006).

The Indian Colony was hidden and inaccessible from the city's main streets until the 1970s, when a small street, Paiute Drive, was created. But while the Indian Colony is clearly marked on many city maps from 1940 to 1969 , most maps produced since then have effaced it. ${ }^{6}$ Indeed, the Las Vegas Indian Colony is a nearly invisible space, one that is simultaneously acknowledged and disavowed by the surrounding non-Indian population. What is it that people do not want to see? The remarks of one recent chairperson of the Las Vegas Paiute Tribal Council at a Senate hearing hint at the reasons:

The Paiutes are one of the oldest Native American Tribes in the United States. Our people have occupied the American Southwest for more than 1,000 years. The Las Vegas Paiutes once occupied all of southern Nevada, eastern California, northern Arizona and southwest Utah. Today we occupy only 121/2 acres (United States Senate, 1983: 30-1).

In a city like Las Vegas, where the normal cycle of capitalist creative destruction is accelerated to the greatest possible degree, these original inhabitants are almost incomprehensible, flickering in and out of the city's field of vision. This near invisibility is paradoxical given that the Indians are in fact the only permanent part of the city and region. There is an interesting and strange similarity between a city that regularly implodes its buildings and a tribe based on a ritualistic nomadism. As Anderson and Mike (1974: 21) explain, when a Paiute dies in a newly built home, "no one would want to live in it' and people move on. Yet despite this superficial similarity between the ephemerality of the capitalist city and Paiute culture, the latter's ritual is grounded in a deep attachment to place. As the tribe's chairperson told a reporter, 'We don't feel we're like most businesses in Las Vegas. If they build something and it doesn't work, they can move on. Las Vegas Paiute don't have that option because they feel the place is what gives them a sense of being' (Hopkins, 1999: 57).

The Paiute Colony is one aspect of Las Vegas' imperial spatialty. The other part involves the military and federal government. In 1854 the US government established a mail run (from Salt Lake City to San Diego, through the oasis that would become Las Vegas); this also involved the construction of a military road for the deployment of troops (Moehring, 2000: 1). By 1905, a railroad from Utah, Arizona and California into Nevada was completed. In the twentieth century, federal spending 'laid the foundation for metropolitan growth' (ibid.: 16). The New Deal decisively changed the region with major public works projects, ranging from the Hoover Dam to the (re)construction of city roads and schools. During the second world war, federal spending intensified with the building of the Basic Magnesium plant. The Hoover Dam project attracted thousands of workers, making 'Hoover City' Las Vegas' first shantytown (ibid.: 18); the Basic Magnesium plant imported black workers from the south, adding public housing projects and another shantytown in the 1940s. In 1940 the Army decided to build an airport and a gunnery school at Las Vegas, and the War Department created a Desert Warfare Center to train soldiers for North African combat (Moehring and Green, 2005: 103). The building of Nellis Air Force Base in 1950 coincided with the creation of the Nevada Test Site (NTS, now called the Nevada National Security Site), a huge territory northwest of the city, where the US military conducted 100 atmospheric nuclear tests between 1951 and 1958, and hundreds of underground tests since then (United States Department of Energy Nevada Operations Office, 2000). Somewhere along the border between the NTS and the Nellis Air Force Range is the infamous Area 51, the CIA's 'most secret domestic military facility', where advanced military technology has been developed since 1955 (Jacobsen, 2011: xi). Area 51 and Nellis have been at the center of the Pentagon's recent drone warfare program and the emerging American 'drone empire' (Shachtman, 2005; Graham,

6 This statement is based on examination of the entire map collection at the University of Nevada, Las Vegas Library's Special Collections site (UNLV, n.d.). 
2011). Currently, around $84 \%$ of Nevada's acreage is federally administered (Harris et al., 2001) and a significant percentage of this land is controlled by the military.

This imperial-military space is interwoven with the historical and colonial territory of the Paiute and Shoshone Indians. As Kuletz (1998: 127) points out, 'the juxtaposition of military and Indian occupation is made clear when the grid of the Nevada Test Site is superimposed on the map of the shelters, springs, camps, and burial sites of the preexisting Indian population'. Many locations inside the NTS are culturally and spiritually significant for the Paiutes, who were originally spread across the entire Great Basin and the deserts surrounding Las Vegas (Stoffle et al., 1994). Inside the NTS there are " "powder rocks" and places where Annual Mourning and other ceremonies were held' (Kuletz, 1998: 127). Many of the Paiutes' 'ancient pathways' converge at Yucca Mountain, inside the NTS. Southern Paiutes believe they cross over Yucca Mountain 'at death in their journey to the afterlife' (ibid.: 132). Since 1987, Republicans have been trying to install a nuclear waste repository within Yucca Mountain, so far without success (Stoffle and Evans, 1988; Rogers, 2012).

The Indians were removed from the NTS when the military assumed control of the space (Kuletz, 1998: 103). Decades of bomb tests have laid waste to the Paiutes' ancestral desert, leaving a toxic irradiated landscape strewn with ruined buildings and vehicles, manmade craters and mangled animal remains, as shown in the brilliant photographs by Richard Misrach (1987). The sacred landscape has become a sacrificial landscape - a territory pummeled, poisoned and proscribed by the American imperial military machine. Las Vegas is inextricably tied to this imperial 'Pentagon Desert' (Davis, 1993: 59; Moehring and Green, 2005: 135, 171).

\section{Imperial culture}

How does Las Vegas' imperial history resonate in the city's casino architecture and self-representations? The design of the city's early casinos emphasized western and pioneer themes. Several casinos that opened after 1945 had Native American themes, including the Apache and the Thunderbird with its 'Wigwam Room', 'Wampum Room' and 'Navajo Room' (Gottdiener et al., 1999: 19; Zook et al., 2009: 201).

With the first bomb tests, the imperial culture of Las Vegas shifted away from images of cowboys and Indians and towards the geopolitics of US hegemony. Illustrations in a government information pamphlet on nuclear tests in Nevada showed cowboys on horseback confronted with and confounded by the mushroom clouds of the new American world order (United States Energy Commission, 1957: 12). The official seal of Clark County, where Las Vegas is located, was a flaming mushroom cloud. The Sands Hotel 'sponsored a Miss Atomic Bomb Contest'. The 'atomic hairdo' became 'a popular request for special occasions' (Titus, 2001: 93). Tourists were treated to views of nuclear explosions (Figure 2) and parade floats featuring papier maché mushroom clouds. The Atomic View Motel offered 'atomic box lunches' to those who wanted to drive closer to observe the blasts (Land and Land, 2004: 114). This form of entertainment continued into the 1990s when Steven Wynne detonated the Dunes Hotel, advertising the event as the 'biggest nonnuclear explosion in the Nevada's history' (Davis, 2002: 85).

The famous neon sign at the Stardust Casino 'offered a panorama of the solar system that exploded beyond the edges of the building', with a plastic earth at the center, 'ringed by a Sputnik', with 'cosmic rays of neon and electric light bulbs puls[ing] out from behind the earth in all directions' (Hess, 1993: 70). As Edward Rothstein observes, 'the original pinkish lettering matched the color of Vegas's radioactive dust', and the Stardust sign 'transformed what was within [the casino] not by pointing to it like a traditional sign, but by pointing somewhere else - here, to the fantastical, explosive possibilities of the atomic space age' (Rothstein, 2013: C7). The sign's font 'became famously known as "Electra Jag" or, more familiarly, "Atomic", (ibid.). 


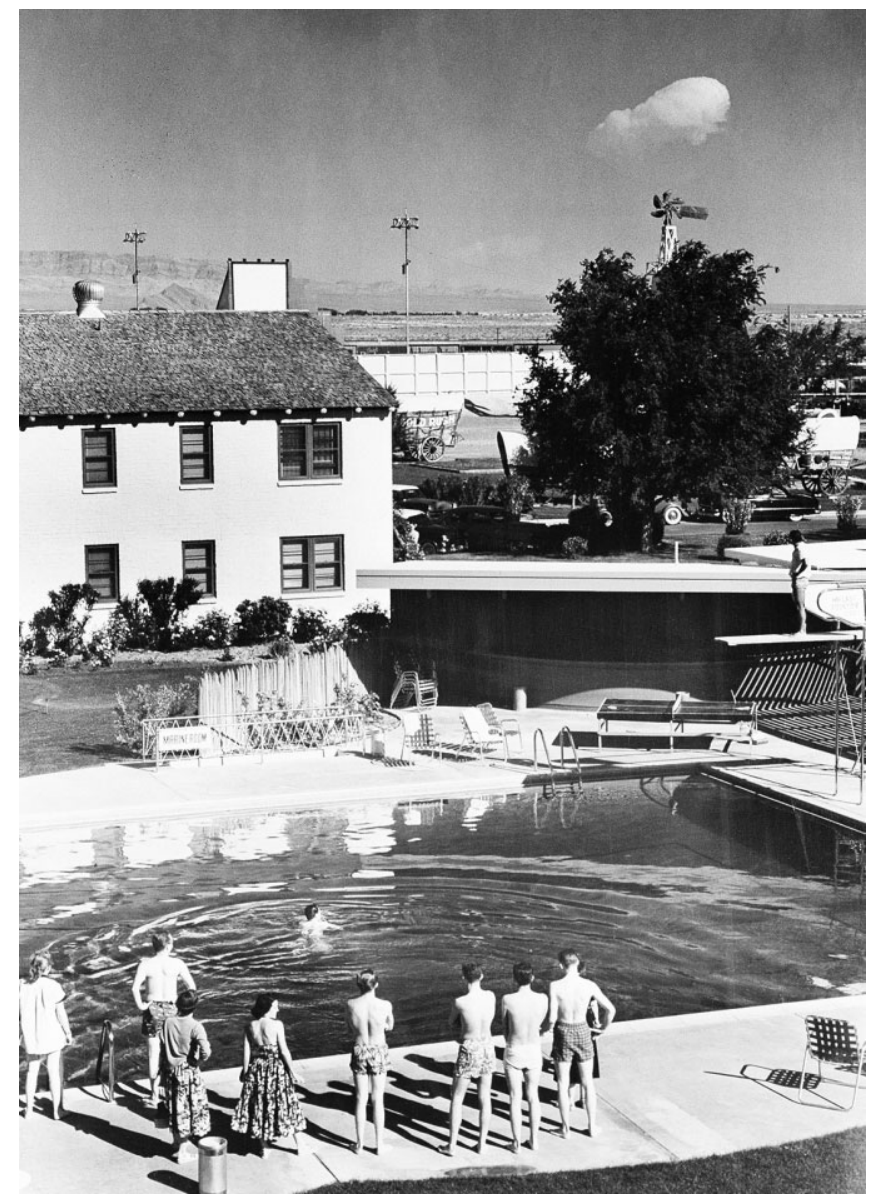

Figure 2 Bathers watching atomic detonation, Las Vegas, 8 May 1953 (reproduced courtesy of Corbis Images)

Another strand of iconic casino images was connected to European colonialism. Many of the new casinos built during the 1950s evoked North or sub-Saharan Africa, areas still under the control of European powers. These included the Desert Inn, the Sands Casino and the Algiers Hotel. The Aladdin Hotel had a 'Baghdad showroom' (Gottdiener et al., 1999: 23). There were 'Arab' motifs at the Dunes Hotel (Figure 3), with its minarettopped neon sign and its giant fiberglass sultan standing astride the porte cochère (Hess, 1993: 55, 80). The decoration of the Sahara suggested a North African desert, with 'plaster statues of camels and Arabs lounging outside' among the palm trees (ibid.: 51). The Sahara had a 'Caravan Room', 'Casbar Lounge', 'Garden of Allah' swimming pool and 'Tunis Tower'. The cursive letters of the 1955 Moulin Rouge sign were curved 'into elegant patterns' like a 'mock-Arabic script - as if invoking the early 20th century's French African colonies' (Rothstein, 2013: C7). The meaning of these representations is not captured by references to a logic of tourism in an age of simulacra. Nor can the meaning of these Las Vegas signs be restricted to an 'Arabian Nights' fantasy (Gottdiener et al., 1999: 87). After all, the Sahara also had a 'Congo Room', with murals of African warriors (Hess, 1993: 50), and a restaurant modeled on the debating chamber of the House of Lords, where British colonial policy for all of Africa and Asia was formulated (Moehring, 2003: 222). Just as postcolonial critics look for the traces of overseas colonies in metropolitan culture, so post-imperial criticism looks for traces of the 


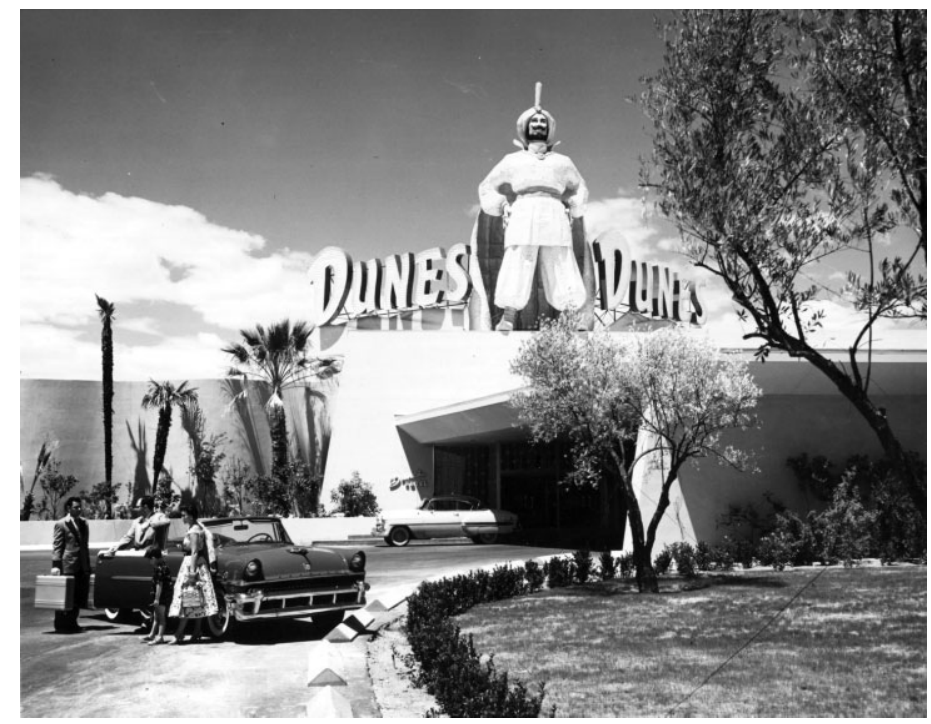

Figure 3 The Dunes Hotel and Casino, 1950s (reproduced courtesy of UNLV, special collections)

American informal empire. It is worth recalling that the empire after 1945 provided the overall geopolitical framework within which European colonial empires lived out their final decades. It makes perfect sense, therefore, that European colonies were represented in Las Vegas (and elsewhere in American culture) in the postwar years, and that they were framed, as it were, by the surrounding 'Pentagon Desert'.

The 1960s marked another transition, with the opening of Caesars Palace in 1966. The aesthetic evolution of Caesars Palace over the past five decades tracks the shift from the relaxed self-confident republic-empire of the early 1960s to today's late-Roman condition, an explosive combination of extreme poverty and luxury with brutal torture-porn militarism. We will focus in on Caesars Palace in a moment.

By the 1990s, the older colonial-themed casinos had given way to giant themed casinos. Critics have discussed this latest version of Las Vegas as an example of the 'disneyization' of cities, their transformation into theme parks (Bryman, 2004; Schmid, 2009). Others compare the city to a world fair, which in our view is the most apt comparison. As Baudrillard (2010 [1986]: 53) observed, 'all great powers have at some time or another created their monumental avenues which provided, as one looked down them, a miniature representation of the infinitude of empire'. In a counterpart to the archipelago of miniature suburban American towns strewn across the worldwide empire of military bases, the external world is symbolically swallowed up and brought home to Las Vegas. Bringing the world's capitals, monuments and great buildings back to the US and rescaling them to fit into a single city is a symbolic gesture of world domination however ironic the gesture is intended to be. Whereas foreign nations were able to carefully craft their own self-presentation at Chicago's 1893 World's Columbian Exposition, for example, this is not the case for the foreign cities and their monuments at the Las Vegas Strip. In this respect Las Vegas more closely resembles Berlin's 1896 Industrial Exposition, a de facto world fair (Osterhammel, 2009: 41-2; Geppert 2010). The 1896 Berlin event included lectures on colonial policy, mock navy maneuvers and a colonial exhibition staffed by indigenous inhabitants of the German colonies. One of the most popular sections of the fair was a miniaturized Egypt called 'Cairo', with scaled-down copies of the Great Pyramid of Giza and famous mosques, a working madrasa and hundreds of Egyptians brought in for the event. 


\section{Caesars Palace: learning from Rome}

By the 1960s the westward course of empire had transformed the former oasis into one of the country's fastest growing metropolitan areas (Stierli, 2010: 79). Completed in 1966, Caesars Palace represented a kind of architectural capstone, built towards the end of the period of self-confident American empire based on a solid Fordist economy. Coexisting with the derelict space of the Paiute Colony, the Caesars Palace of 1966 is crucial to this era of cars, casinos and the atom bomb.

We need to bear in mind, however, that discussing Caesars Palace means discussing two different structures, one belonging to the early, the other to the late, postmodern era; i.e. the original building, which is the object of analysis in Venturi, Scott Brown and Izenour's Learning from Las Vegas ( $L L V)$, and the remodeled contemporary version, completed in the 1990s. The first version represented imperial Roman architecture as serious parody, the second as dead serious parody. The concept of parody permeates much of the recent literature on Las Vegas, including LLV. Bégout (2003: 13) understands the city's parody in an existential sense: Las Vegas mocks everything, "pulps all human events into an electrochemical swill of parody'. The site of radical alienation, the city turns 'others into total strangers' by thoroughly ridiculing 'all the culture and civilization that signals [the] presence [of others]' (ibid.). We approach the question of parody from a different angle. Since the beginning, American discourse about empire has been characterized by a tension between the desire to embrace empire and the desire to distance the newly independent colony from empire (Hell, 2014). An architectural example of this tension is the neoclassical building nestled among the skyscrapers of Wall Street, the Federal Hall National Memorial, built in 1833-34. Inspired by the Parthenon, the building's exterior design 'suggests a reverence for Greek democracy'. By contrast, its interior 'brings to mind the economic power of the Roman Empire' by mimicking the Pantheon. ${ }^{7}$ This gesture of (sometimes ironic) distance from empire shows up in Caesars Palace as the parody of imperial Rome.

Discussing Las Vegas' simulacra, Arthur Danto (2000: 352) observed that Caesars Palace was the only hotel that did not replicate any 'known structure of Imperial Rome'. In Danto's view, this makes it the only authentic Las Vegas hotel, representative of nothing but the city itself (ibid.). Yet it is precisely this imaginary quality that makes Caesars Palace the symbolic post-Roman site of imperial power. Participating in the guessing game that is provoked by the Roman 'copy' (Franci, 2005: 64), Danto found its model in the Vittoriano, a monument with deep roots in Rome's imperial past. ${ }^{8}$

Like Danto, Alan Hess uncovers post-Roman imperial traces in his analysis of the original Caesars Palace. Hess wants to claim this structure as an example of historicist modernism. Instead of looking for models from imperial Rome, architect Melvin Grossman imitated the 'grand prospects of Baroque Rome' (Hess, 1993: 84): a copy of Nike standing at the head of a set of fountains, the 14-storey tower rising behind her flanked by 'modernistic colonnade[s]' (ibid.: 86). This historicism, 'a true popular culture appropriation of high-art forms', did not lay any claim to 'accuracy' (ibid.: 86, 84). Nonetheless Hess also notices architectural allusions to imperial Rome. Most intriguingly, he compares the casino's interior to Hadrian's Villa at Tivoli, whose rooms and gardens were designed 'to remind [the emperor] of the many parts of his empire' (ibid.: 87). To this, we should add the famous casino sign, combining the facade of a Roman temple with fiberglass statues of Roman centurions.

The construction of Caesars Palace in 1966 inaugurated the era of themed casinos, which gradually transformed the entire Strip into a flashy array of 'crudely constructed attempts to encapsulate human history' from antiquity to the present (Bégout, 2003: 41).

7 Quotations from informational plaque outside Federal Hall National Memorial, New York City.

8 The Vittoriano's opening in 1911 was accompanied by an exhibition, the Mostra Archeologica, displaying the ancient empire's vast reach (Strong, 1911). Later, the monument became part of Mussolini's geopolitics of romanità (Atkinson and Cosgrove, 1998: 37). 
By 1999, Caesars Palace had been remodeled in ways that do indeed recall the Vittoriano's outsized monumentalism. Like this other 'colossal monstrosity' (Atkinson and Cosgrove, 1998: 29), Caesars Palace is now a massive glaringly white structure with two additional hotel towers (the Augustus and the Octavian) and a performance space (the Colosseum). Remodeled with archeological authenticity in mind, the entire casino complex is covered with copies of Roman statuary and friezes; it now also includes high-end shopping malls, named after the Roman Forum and the Appian Way. The marble and gilded plaster of the new rotundas and entrance ways, together with the many Davids and Apollos, quadrigas and winged creatures, signal imperial grandeur and authenticity. The casino's website insists on historical authenticity, informing visitors that the Caesar Augustus statue is based on the statue in the Vatican's museum, and listing 'elements from ancient Rome' in the hotel's lobby - mosaics, friezes, etc.

The hotel's garishly colored fiberglass centurions have disappeared. Heavily decorated with stucco and gold, the new sign standing atop a triumphal arch combines Roman elements with large video screens. Close to the casino stands another grandiose arch-sign, bearing gilded statues (Franci, 2005: 83). In the casino itself, 'staff dressed as Roman aristocrats and soldiers' mingle with the visitors (Raento and Flusty, 2006: 104). One of Hess' (1993: 114) photographs shows a poster directing visitors 'Inward to the Empire'. Guests find in their rooms a hotel magazine entitled Empire: A Publication for the Caesars Palace Enthusiast, whose layout suggests dark luxury rather than the frivolity of the fiberglass centurions (Figures 4 and 5).

Despite its aspirations towards archeological accuracy, all of this is still 'a muddle that would have Vetruvius thoroughly perplexed' (Bégout, 2003: 27). Franci (2005: 87) calls the jumble of styles 'inaccurate but imaginative', which brings us back to our post-imperial approach. The Caesars Palace of 1966 represented imperial Rome in the mode of parody, albeit serious parody: a Mafia version of metropolitan decadence resonating with Mussolini's monumentalism that functioned well for the new world power in the atomic age. The self-confidence that sustains ironic gestures is now lost. The fiberglass centurions - pure schlock - exuded an imperial self-confidence that is palpably absent in the current self-representation of Caesars Palace, which aggressively combines Roman might with Roman luxury. Today's 'Schlock-and-Awe' (Knox, 2008: 155) version of Caesars Palace is dead serious parody, combining supposed archeological accuracy with monumentality on a new scale. This truly massive structure functions in a fetishistic mode, denying the end of empire by resurrecting the Roman empire in a monstrously massive and massively stable form.

\section{Scott Brown, Venturi and the Fordist aesthetics of post-Roman empire}

Franci argues that Las Vegas' 'ensemble of copies' succeeded in translating the Grand Tour for the age of mass culture and virtual reality. Lacking respect for the Roman original, architects produced something new, making room for 'imagination and excess' (Franci, 2005: 66). We would argue that Las Vegas reinvented post-Roman mimesis in a form that was suited to an empire at its peak, the Fordist era of mass consumption and a shared Hollywood mass culture, and that the new Las Vegas is suited to an era of waning imperialism, a post-Fordist culture of excess with its 'degenerate utopia' of 'shopertainment' (Knox, 2008: 157).

Scott Brown and Venturi famously attacked this critical view of Las Vegas, asking their colleagues to 'like what one does not like' (quoted in Golec, 2009: 37): the city as 'commercial strip'. The Las Vegas they knew was a city of democracy, embodying the taste of the 'silent white majority', its architecture one of 'inclusion' (Venturi et al., 1972: 154, 53). The architects discovered their populist Fordist aesthetic while driving through the city in 1966 after having dropped in on Ed Ruscha, Scott Brown's friend. 

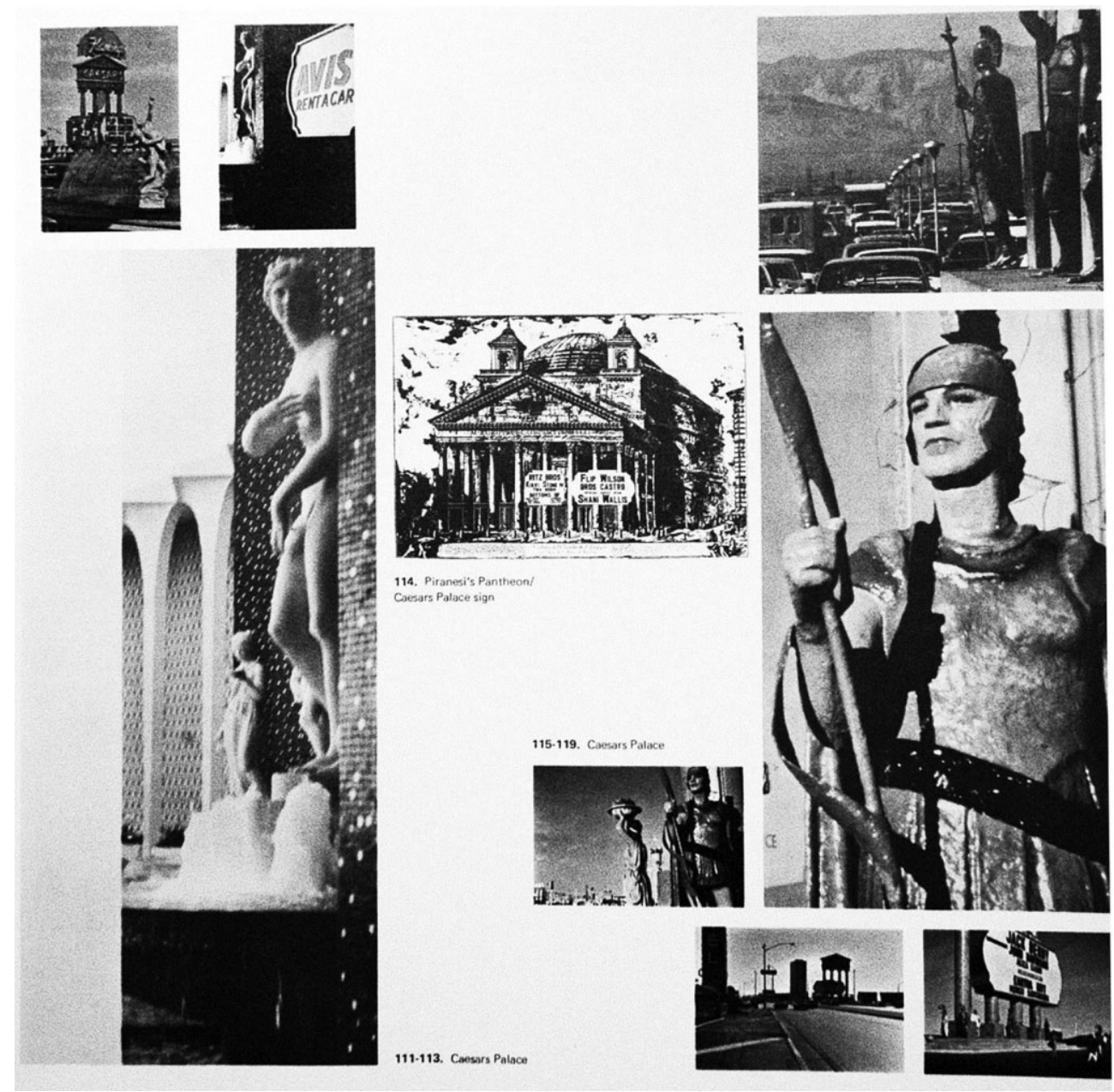

Figure 4 Montage from original edition of LLV (source: Venturi et al., 1972: frontispiece and p. 51 of Learning From Las Vegas, (c) Massachusetts Institute of Technology, reproduced by permission of The MIT Press)

The original edition of $L L V$ includes a collage surrounded by photographs of the old Caesars Palace sign and its centurions, showing Piranesi's engraving of the Roman Pantheon decorated with neon signs (middle), fiberglass Roman centurions (left) looking out over the parking lot and figures (Figure 4). Suggesting an analogy between Piranesi's ruined Pantheon and the 'decorated shed' of Caesars Palace, the architects visualize the post-imperial spatiality that they hint at but never explicitly theorize.

The Rome-US axis in which ancient Rome functions as 'the other homeland in our Western culture' (Venturi, 1996: 54) grounds the theorists' revitalization of modernism. As in Ratzel's Political Geography, this Rome-US axis designates an imperial spatiality; in this case it is tied to the reinvention of twentieth-century architecture. Comparing the architects of Las Vegas to those of the Renaissance, Venturi et al. (1977: 106) write: 'The iconography of Renaissance architecture is less overtly propagandistic than is that of . . Strip architecture, although its ornament, literally based on the Roman, Classical vocabulary, was to be an instrument for the rebirth of classical civilization'. In the Renaissance, these ornaments are all 'explicitly symbolic, associating the glories of Rome with the refinements of building' (ibid.: 107). Las Vegas architecture revitalized 


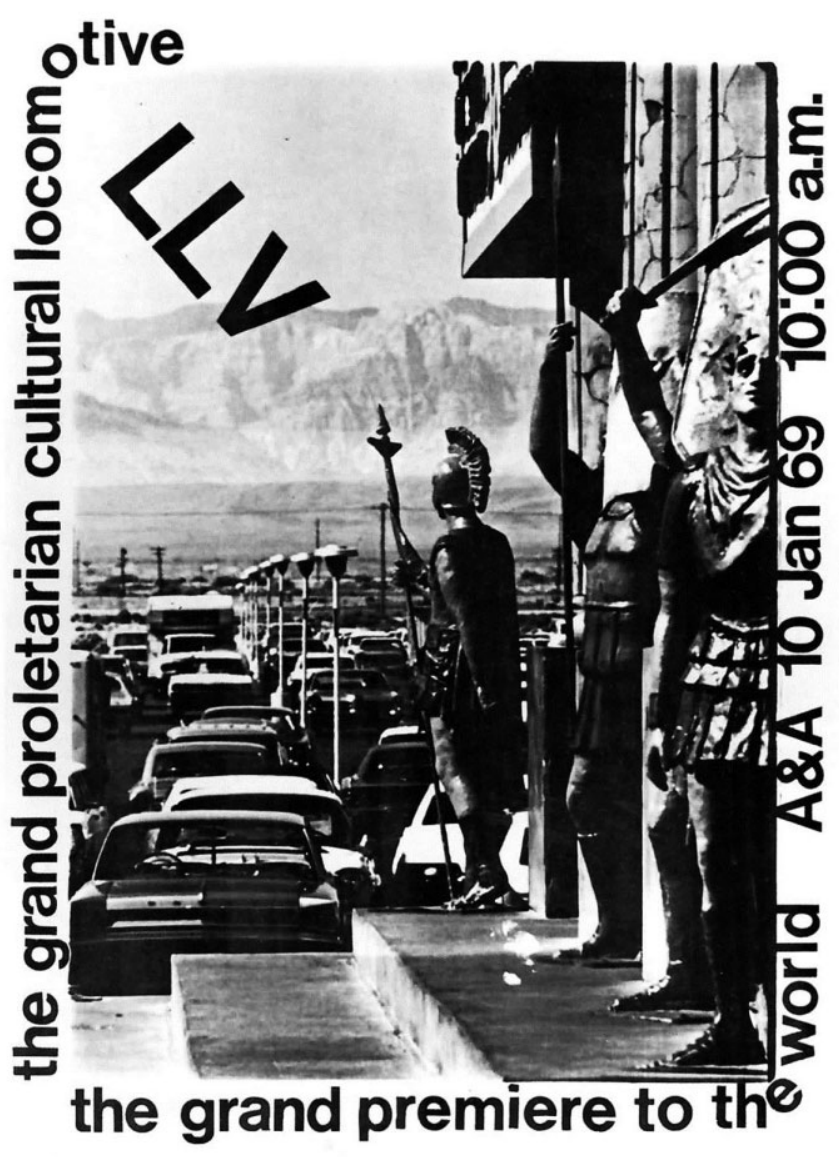

Figure 5 Poster invitation to the final presentation of the 'Learning from Las Vegas Research Studio', Yale University, 10 January 1969 (source: Venturi et al., 1972: frontispiece and p. 51 of Learning From Las Vegas, (c) Massachusetts Institute of Technology, reproduced by permission of The MIT Press)

modernism by returning to this citational practice. What Scott Brown and Venturi found in Las Vegas was a modernist architecture of content, ironic reminders 'of something else' (ibid.: 53). The authors' main example of this revolutionary architecture is the sign at Caesars Palace, "where a freestanding, pedimented temple facade was extended laterally by one column with a statue on top'; this was, they wrote, 'a feat never attempted, a problem never solved in the whole evolution of Classical architecture' (ibid.: 106). The poster for their 1979 Yale studio foregrounds this revolutionary nature of Las Vegas' vernacular modernism, showing the centurions as they 'peer ... across their desert empire' (Venturi and Scott Brown, 1968: 42; see Figure 5). LLV also includes the casino's brochure, which claims that the casino's collection of statuary recalls 'the grandeur that was Rome' (Venturi et al., 1977: 56-7). Caesars Palace itself is thus the place where imperial Rome is reinvented in the ironic mode. A decorated shed, Caesars Palace proclaims: I am Rome.

Like Caesars Palace, the Strip as a whole reinvents Roman architecture: 'The Forum, like the Strip ... was a landscape of symbols' (ibid.: 117). Comparing billboards on Route 66 to triumphal arches, they note their similar functions as 'spatial markers' (ibid.). More importantly, they both function symbolically: 'Along the highway, advertising Tanya via graphics and anatomy, like advertising the victories of Constantine 
via inscriptions and bas-reliefs, is more important' (ibid.). Looking back at the year he spent at the American Academy in Rome, Venturi (1996: 51) wrote that he discovered the 'relevance of Rome at a moment in the mid-twentieth century'. Taking this imperial text into account we argue that Learning from Las Vegas turns around the question of how to imitate the architecture of imperial Rome in the modern age. In 'The Significance for A\&P Parking Lots', Venturi and Scott Brown (1968) develop their aesthetics of post-Roman imperial mimesis using Richard Poirier's (1967) comments on parody, imitation and the 'de-creative imagination'. This form of imagination raids the past for 'images that have retained their vitality' (Venturi and Scott Brown, 1968: 37). The 'Las Vegas of the classical age' is vital, they argue implicitly, because it mimics the style of the Rome of the classical age.

In 1994, the architects returned to Las Vegas, distinguishing the old mimicked style from the 'unconvincing irony' of the new city (Venturi and Scott Brown, 1996: 128). In other words, what they once saw as Caesars Palace's ironic, 'vivid, vulgar, and vital [folk art]' (ibid.) has become dead serious parody. Once more they gesture at the connection between this new bombastic style and hypertrophic American empire without thematizing it explicitly.

\section{Conclusion: neon unplugged}

As soon as the Soviet empire began to crumble, Socialist Realist monuments across Eastern Europe started disappearing. Weary of what they saw as a collective desire for amnesia, Hungarian intellectuals proposed the creation of Budapest's Statue Park. Opened in 1993 and located on the city's outskirts, this collection of monumental statues was later renamed Memento Park. Las Vegas' new open-air museum, the Neon Museum, does not display statues of Lenin - nor does it lure its visitors with statues of Frémont, Benjamin Siegel (the Mafia boss who built the first of the non-western style casinos, the Flamingo) or Steve Wynn (the owner of the Bellagio, a mega-resort built in the 1990s). Instead, the Neon Museum exhibits architectural fragments and neon signs from Las Vegas' 'classical age', some of them iconic signs made by the Young Electronic Sign Company (YESCO) for the Strip's most famous casinos, others donated before buildings were demolished or rescued from the rubble after destruction.

Before the Neon Museum, there was the popular Neon Boneyard, a yard where YESCO stored broken or obsolete signs (Stierli, 2010: 244). In Zeropolis, Bruce Bégout (2003) discusses this old derelict Boneyard on the edge of the desert. Fascinated by the sight, Bégout (ibid.: 32) does not want to dismiss the signs as mere 'relics of a market and consumer culture born in the 1950s'. Since they are no longer compelled to signify by this culture, the discarded signs have acquired a new beauty; they are works of art (or at least hint at what they once were in the imagination of the artists who created them). In Bégout's eyes, the old Boneyard is a museum of 'Pop Art' (ibid.: 32). Similarly, Houston (2013: 104) found 'unexpected dignity' in the old Neon Boneyard.

The signs at the new Neon Museum's version of the Boneyard are still untouched, preserved in a state of 'disrepair' (Rothstein, 2013: C7; see Figure 6). On this new site, the slowly rusting neon steel signs from the old Boneyard are reintegrated into the city's capitalist economy. ${ }^{9}$ They are, as Bégout would argue, once more compelled to signify, this time as objects of nostalgia. That is, in the new museum, the old signs now function as relics of the heroic age of American capitalism, the age of cars, casinos and atom bombs conjuring the populist myth of the old 'authentic' Las Vegas Strip (the period from roughly the 1940s to the 1970s).

9 The set of signs that the museum's curators recently installed on some downtown streets were restored to their former garish brightness (Glionna, 2012). 


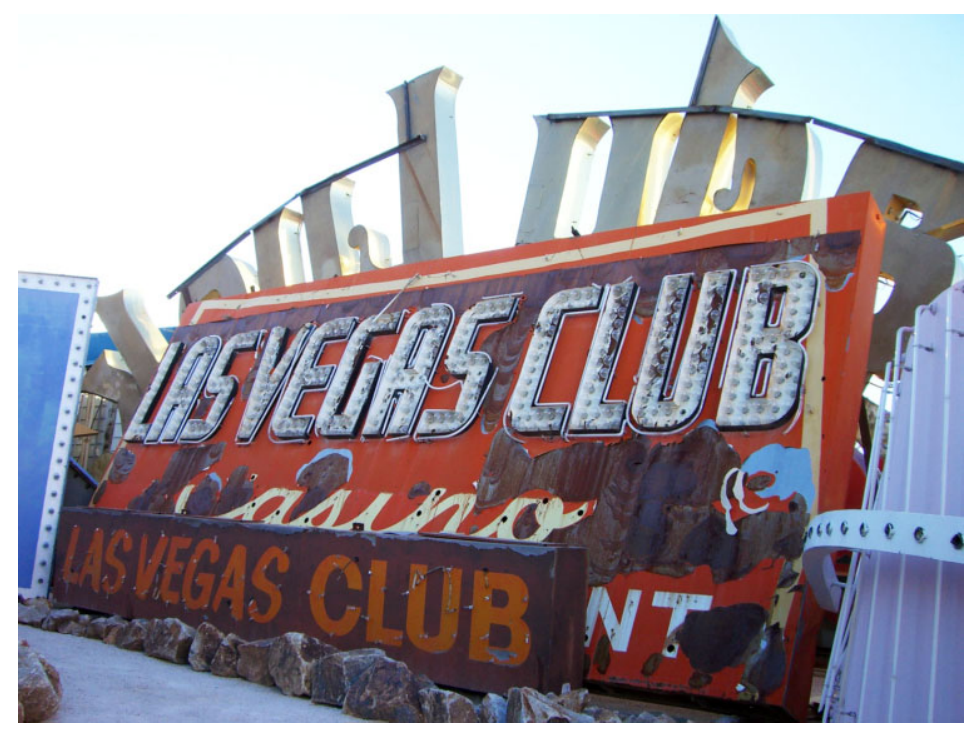

Figure 6 Neon signs in the outdoor boneyard of the Las Vegas Neon Museum (source: photo by Nic Heckner, 2013; (c) The Neon Museum, Inc., reproduced with permission)

Yet the old Boneyard's decaying signs also signify on another level. These signs, which include the 'super-pylon' of the original Caesars Palace (Johnson et al., 2012: 52), are, we think, imperial ruins specific to an American metropolis in the midst of the great desert, in a territory once occupied by the Southern Paiute and Shoshone. To call discarded neon signs 'captivating ruins', or even imperial ruins, may seem counterintuitive (Stickells and Sully, 2010: 60). But there may be good reasons for doing so. The first reason for defining these particular material remnants as ruins has to do with Venturi, Scott Brown and Izenour's text. Driving through Las Vegas in 1969, they analyzed the effect of a new urban landscape of communication. They argued that it was the city's signs that mattered, not its buildings. Discovering American populism, they celebrated the city's 'decorated sheds'. ${ }^{10}$ When the buildings from this era were demolished - a spectacle that has occurred with monotonous regularity in Las Vegas it was the signs decorating the 'sheds' that were left behind and often preserved. In this city the signs, not the buildings, are the ruins languishing in the desert heat (ibid.: 62).

The second reason has to do with the more general question of what makes a ruin, or more specifically an imperial ruin. The issue at stake is framing - an issue that we discussed in the context of recent debates about the end of the American empire and the attendant remobilization of the trope of imperial ruin gazing. In the present context, the ruins recently enshrined in the Neon Museum now signify the slow demise of the American empire. '[W]itnesses of a swift life' (Ratzel, 1876: 249), they are post-Roman ruins of a new kind that Ratzel would have loved. Whether this is 'a decline that will occur just as rapidly as the lifestyle that created them' (ibid.) remains of course an open question.

This reading of the Neon Museum's Boneyard does not exhaust its meanings. For, like Caesars Palace in its current incarnation, the Neon Museum ultimately attempts to deny ruination. As we argued above, the new museum reintegrated the ruin signs of the old Boneyard (belonging to the early era that Caesars Palace defined retroactively as imperial) into the city's capitalist culture. It did so 'by tidying things up, removing the

10 Their shed is the answer to what they called late modernism's elitist 'ducks', or buildings that were sculptures. 
bits of rust that might catch on sleeves' (Houston 2013: 110) — in other words, the curators recreated the space of the old Boneyard in a form suited to the new Vegas. On the site of the Neon Museum, the old Boneyard's ruin signs have become objects of art displayed with an eye towards their aesthetic value. This is done in ways that paradoxically gesture at what Scott Brown and Venturi defined as their revitalized modernist aesthetic with its odd mix of populism and high art. ${ }^{11}$ Through this allusion to Learning from Las Vegas, the ruin signs in the Neon Museum are made to participate in the commercial culture of Wynne's new Las Vegas with all of its artistic pretentions. ${ }^{12}$ Like a true fetish, the Neon Museum thus both acknowledges and denies ruination - the ruination of signs, a city and an empire.

Julia Hell (hell@umich.edu), Department of German, University of Michigan, 1139 Thayer, 12 East Washington Street, Ann Arbor, MI 48109, USA and George Steinmetz (geostein@umich.edu), Department of Sociology, University of Michigan, 500 South State Street, Ann Arbor, MI 48104, USA.

\section{References}

Aglietta, M. (1979) A theory of capitalist regulation: the US experience. NLB, London.

Alley, J. (1977) The Las Vegas Paiutes: a short history. University of Utah, Salt Lake City.

Anderson, K. and D. Mike (1974) History of the Las Vegas Indian Colony. In Inter-Tribal Council of Nevada (ed.), Personal reflections of the Shoshone, Paiute, Washo, Inter-Tribal Council of Nevada, Carson City, NV.

Atkinson, D. and D. Cosgrove (1998) Urban rhetoric and embodied identities: city, nation, and empire at the Vittorio Emanuele II monument in Rome, 1870-1945. Annals of the Association of American Geographers 88.1, 28-49.

Bassin, M. (2003) Politics from nature. Environment, ideology, and the determinist tradition. In J. Agnew, K. Mitchell and G. Toal (eds.), A companion to political geography, Blackwell Publishers, Malden, MA.

Baudrillard, J. (2010 [1986]) America. Verso, London.

Bégout, B. (2003) Zeropolis: the experience of Las Vegas. Reaktion, London.

Bergesen, A. and C. Sahoo (1985) Evidence of the decline of American hegemony in world production. Review 8.4, 595-611.
Borchard, K. (2011) Homeless in Las Vegas. Stories from the street. University of Nevada Press, Reno.

Bryman, A. (2004) The disneyization of society. Sage, London.

Burbank, J. (1991) Las Vegas Indian colony well-guarded. Small-town approach works for Paiute cops. Las Vegas Review-Journal 24 February, 1B.

Calloway, C.G. (2006) The scratch of a pen: 1763 and the transformation of North America. Oxford University Press, Oxford.

Citizens against Government Waste (2010) Why do great nations fail? [WWW document]. URL http://www.youtube.com/ watch? $\mathrm{v}=$ OTSQozWP-rM. (accessed 8 January 2013).

Danto, A.C. (2000) Degas in Vegas. In A.C. Danto, The madonna of the future: essays in pluralistic art world, University of California Press, Berkeley.

Davis, M. (1993) Dead west: ecocide in Marlboro country. New Left Review 200 July/August, 49-73.

Davis, M. (2002) Dead cities. The New Press, New York.

Driver, F. and D. Gilbert (eds.) (1999) Imperial cities: landscape, display and identity. Manchester University Press, Manchester.

11 We say paradoxically because of Scott Brown and Venturi's stated dislike for this new Vegas.

12 Wynn sold the Bellagio in 2000, but his collection of paintings by European masters is still on display in the resort's Gallery of Fine Art (Minca, 2005: 112). 
Federal Register (2012) Indian entities recognized and eligible to receive services from the Bureau of Indian Affairs [WWW document]. URL http://www.gpo.gov/ fdsys/pkg/FR-2012-08-10/pdf/2012 -19588.pdf (accessed 9 September 2013).

Finnegan, A. (2011) With demise of Sahara, what's next for North Las Vegas Strip? Las Vegas Sun 13 May [WWW document]. URL http://www.vegasinc.com/ news/2011/may/13/demise-sahara-whats -next-north-strip/ (accessed 16 October 2013).

Franci, G. (2005) Dreaming of Italy: Las Vegas and the virtual grand tour. University of Nevada Press, Reno.

Garcia, O. (2011) Adults get life-sized sandbox near Las Vegas Strip. Las Vegas Sun 2 Sept [WWW document]. URL http:// www.lasvegassun.com/news/2011/sep/02/ us-sin-city-sandbox-1st-ld-writethru/ (accessed 16 October 2013).

Garrahan, M. (2011) Poverty crisis in US gambling paradise. Financial Times 31 August [WWW document]. URL http:// www.ft.com/cms/s/0/56d4b27c-c9b3-11e0 -b88b-00144feabdc0.html\#axzz2rWsrcpsI (accessed 26 January 2014).

Geppert, A.C.T. (2010) Fleeting cities: imperial expositions in fin-de-siècle Europe. Palgrave Macmillan, Basingstoke.

Glionna, J.M. (2012) Neon museum illuminates old-school Las Vegas. Los Angeles Times 30 October [WWW document]. URL http://articles.latimes .com/2012/oct/30/nation/la-na-vegas -neon-20121030 (accessed 26 January 2014).

Gold, H. (2011) Las Vegas looks a lot like the new Detroit. Market Watch 13 May [WWW document]. URL http://articles .marketwatch.com/2011-05-13/ commentary/30795671_1_las-vegas-strip -gambling-revenues-and-wynn-resorts. (accessed 9 December 2012).

Golec, M.J. (2009) Format and layout in learning from Las Vegas. In A. Vinegar and M.J. Golec (eds.), Relearning from Las Vegas, University of Minnesota Press, Minneapolis.

Gottdiener, M., C.C. Collins and D.R. Dickens (1999) Las Vegas. The social production of an all-American city. Blackwell, Oxford.

Graham, S. (2011) Cities under siege. The new military urbanism. Verso, London and New York.
Hansel, M. (2006) Looking in on city hall. Las Vegas Sun 6 November [WWW document]. URL http://www.lasvegassun .com/news/2006/nov/06/looking-in-on -city-hall/ (accessed 16 October 2013).

Harris, T.R., W.W. Riggs and J. Zimmerman (2001) Public lands in the state of Nevada: an overview. University of Nevada, Reno [WWW document]. URL http://www .unce.unr.edu/publications/files/cd/2001/ fs0132.pdf (accessed 16 October 2013).

Hell, J. (2008) Ruins travel: orphic journeys through 1940s Germany. In J. Zilcosky (ed.), Writing travel, University of Toronto Press, Toronto.

Hell, J. (2009) Katechon: Carl Schmitt's imperial theology and the ruins of the future. The Germanic Review 84.4, 283-326.

Hell, J. (2010) Imperial ruin gazers, or why did Scipio weep? In J. Hell and A. Schoenle (eds.), Ruins of modernity, Duke University Press, Durham, NC.

Hell, J. (2014) Ruin gazing: Western imperialism and the fall of Rome. University of Chicago Press, Chicago.

Hell, J. and A. Schoenle (eds.) (2010) Ruins of modernity. Duke University Press, Durham, NC.

Hess, A. (1993) Viva Las Vegas: after-hours architecture. Chronicle Books, San Francisco.

Hobson, J.A. (1965) Imperialism, a study. University of Michigan Press, Ann Arbor.

Hopkins, A D. (1999) Returning to the land. Las Vegas Review-Journal 12 (September), 57.

Houston, D. (2013) Junk into urban heritage: Neon Boneyard, Las Vegas. Cultural Geography 20.1, 103-11.

Huber, N. and R. Stern (2010) Las Vegas from excess to environment. In D. Valentien (ed.), Wiederkehr der Landschaft/return of landscape, Akademie der Künste, Berlin.

Inter-Tribal Council of Nevada (1976) Nuwuvi: a Southern Paiute history. Inter-Tribal Council of Nevada, Reno.

Jacobsen, A. (2011) Area 51. An uncensored history of America's top secret military base. Little, Brown \& Co, New York.

Johnson, C.A. (2010) Dismantling the empire: America's last best hope. Metropolitan Books, New York. 
Johnson, M., C. Schomig and D. Wright (eds.) (2012) Spectacular. A history of Las Vegas neon. The Neon Museum, Las Vegas.

Kennedy, P.M. (1987) The rise and fall of the great powers: economic change and military conflict from 1500 to 2000. Random House, New York.

King, A.D. (1976) Colonial urban development: culture, social power, and environment. Routledge \& Paul, London.

Knack, M.C. (2001) Boundaries between: the Southern Paiutes, 1775-1995. University of Nebraska Press, Lincoln.

Knox, P.L. (2008) Metroburbia, USA. Rutgers University Press, New Brunswick, NJ.

Kuletz, V. (1998) The tainted desert: environmental ruin in the American West. Routledge, New York.

Land, B. and M. Land (2004) A short history of Las Vegas. Second edition, University of Nevada Press, Reno.

Las VegasMichael (2012) The Roman ruins of Las Vegas [WWW document]. URL http:// www.allvegaspoker.com/news_detail 518.html (accessed 15 April 2012).

LasVegas Paiute Tribe (2013) Departments webpage [WWW document]. URL http:// www.lvpaiutetribe.com/index-2.html (accessed 9 September 2013).

Louis, W.R. and R. Robinson (1994) The imperialism of decolonization. The Journal of Imperial and Commonwealth History 22.3, 462-511.

Lutz, C. (ed.) (2009) The bases of empire. The global struggle against US military posts. New York University Press, New York.

Minca, C. (2005) Bellagio and beyond. In C. Cartier and A.A. Lew (eds.), Seductions of place: geographical perspectives on globalization and touristed landscapes, Routledge, London.

Misrach, R. (1987) Desert cantos. University of New Mexico Press, Albuquerque.

Moehring, E.P. (2000) Resort city in the sunbelt: Las Vegas, 1930-2000. Second edition, University of Nevada Press, Reno.

Moehring, E.P. (2003) The Sahara Hotel: Las Vegas 'jewel in the desert'. In K. Jaschke and S. Ötsch (eds.), Stripping Las Vegas: a contextual review of casino resort architecture, Universitätsverlag, Bauhaus-Universität Weimar, Weimar.

Moehring, E.P. and M.S. Green (2005) Las Vegas: a centennial history. University of Nevada Press, Reno.
National Intelligence Council (2012) Global trends 2030: alternative worlds [WWW document]. URL http://www.dni.gov/files/ documents/GlobalTrends_2030.pdf. (accessed 8 January 2013).

NYFA (New York Foundation for the Arts) (n.d.) Dusk falls on an empire. Nick Stillman [WWW document]. URL http:// www.nyfa.org/level3.asp?id=424\&fid $=6 \&$ sid $=17 \&$ print $=$ true $($ accessed 10 January 2013).

O'Brien, M. (2007) Beneath the neon: life and death in the tunnels of Las Vegas. Huntington Press, Las Vegas.

O'Brien, M. (2010) My week at the Blue Angel and other stories from the storm drains, strip clubs, and trailer parks of Las Vegas. Huntington Press, Las Vegas.

OccupyLV (2012) Vegas is dying for work [WWW document]. URL http://www .occupylv.org/news/vegas-dying-work (accessed 10 January 2013).

Osterhammel, J. (2009) Die Verwandlung der Welt: eine Geschichte des 19.

Jahrhunderts [The transformation of the world: a history of the nineteenth century]. Beck, München.

Poirier, R. (1967) T.S. Eliot and the literature of waste. New Republic 156.20, 19-25.

Raento, P. and S. Flusty (2006) Three trips to Italy: deconstructing the new Las Vegas. In C. Minca and T. Oakes (eds.), Travels in paradox: remapping tourism, Rowman \& Littlefield Publishers, Lanham, MD.

Ratzel, F. (1876) Städte- und Culturbilder aus Nordamerika [Sketches of urban and cultural life in North America]. F.A. Brockhaus, Leipzig.

Ratzel, F. (1882) Anthropo-Geographie, oder Grundzüge der Anwendung der Erdkunde auf die Geschichte [Anthropo-geography, or fundamentals of the application of geography to history]. J. Engelhorn, Stuttgart.

Ratzel, F. (1897) Studies in political areas: the political territory in relation to earth and continent. American Journal of Sociology 3.3, 297-313.

Ratzel, F. (1923 [1897]) Politische Geographie [Political geography]. Third edition, R. Oldenbourg, München.

Ratzel, F. (1988 [1876]) Sketches of urban and cultural life in North America. Rutgers University Press, New Brunswick, NJ. 
Reeve, W.P. (2006) Making space on the western frontier: Mormons, miners, and Southern Paiutes. University of Illinois Press, Urbana.

Rockwell, S.J. (2010) Indian affairs and the administrative state in the nineteenth century. Cambridge University Press, Cambridge.

Rogers, K. (2012) 'Screw Nevada' bill ignited outrage then, now. Las Vegas Review-Journal 22 December, B1.

Rothman, H. (2002) Neon metropolis: how Las Vegas started the twenty-first century. Routledge, New York.

Rothman, H. (2003) The shape of the city money and the visual face of Las Vegas. In K. Jaschke and S. Ötsch (eds.), Stripping Las Vegas: a contextual review of casino resort architecture, Universitätsverlag, Bauhaus-Universität Weimar, Weimar.

Rothstein, E. (2013) Where Las Vegas stardust rests in peace. New York Times (national edition) 2 February, C1, C7.

Schmid, H. (2009) Economy of fascination. Dubai and Las Vegas as themed urban landscapes. Gebrüder Borntraeger, Berlin.

Schmitt, C. (1950) Der Nomos der Erde im Völkerrecht des Jus Publicum Europaeum [The nomos of the earth in the international law of the Jus Publicum Europaeum]. Greven, Cologne.

Segall, E. (2012) Developers eye Las Vegas valley's unfinished buildings. Las Vegas Sun 12 November [WWW document]. URL http://www.vegasinc.com/news/2012/ nov/12/developers-eye-las-vegas-valleys -unfinished-buildi/ (accessed 16 October 2013).

Shachtman, N. (2005) Attack of the drones. Wired 13.06 [WWW document]. URL http://www.wired.com/wired/archive/13.06/ drones.html (accessed 16 October 2013).

Steinmetz, G. (2005) Return to empire: the new US imperialism in theoretical and historical perspective. Sociological Theory 23.4, 339-67.

Steinmetz, G. (2012) Geopolitics. In G. Ritzer (ed.), The Wiley-Blackwell encyclopedia of globalization, volume II, Wiley-Blackwell, Malden, MA.

Stickells, L. and N. Sully (2010) Haunting the boneyard. In G. Pye (ed.), Trash culture: objects and obsolescence in cultural perspective, Peter Lang, Oxford.

Stierli, M. (2010) Las Vegas im Rückspiegel: die Stadt in Theorie, Fotografie und Film [Las Vegas in the rearview mirror: the city in theory, photography and film]. GTA Verlag, Zürich.

Stockholm International Peace Research Institute (2012) The SIPRI military expenditure database [WWW document]. URL http://milexdata.sipri.org/ (accessed 16 October 2013).

Stoffle, R.W. and M.J. Evans (1988) American Indians and nuclear waste storage: the debate at Yucca Mountain, Nevada. Policy Studies Review 16.4, 751-67.

Stoffle, R.W., M.J. Evans, D.B. Halmo, M.E. Dufort and B.K. Fulfrost (1994) Native American cultural resources on Pahute and Rainer Mesas, Nevada test site. Bureau of Applied Research in Anthropology, Tucson, AZ.

Strong, S.A. (1911) The exhibition illustrative of the provinces of the Roman empire, at the baths of Dioclectian. The Journal of Roman Studies 1, 1-49.

Suskind, R. (2004) Faith, certainty and the presidency of George W. Bush. New York Times Magazine 17 October, 44-51, 64, 102, 106.

Titus, A.C. (2001) Bombs in the backyard: atomic testing and American politics. Second edition, University of Nevada Press, Reno.

Trennert, R.A. (1975) Alternative to extinction: federal Indian policy and the beginnings of the reservation system, 1846-51. Temple University Press, Philadelphia, PA.

United States Department of Energy Nevada Operations Office (2000) United States nuclear tests, July 1945 through September 1992 [WWW document]. URL http:// www.nv.doe.gov/library/publications/ historical/DOENV_209_REV15.pdf (accessed 16 October 2013).

United States Energy Commission (1957) Atomic tests in Nevada. US Government Printing Office, Washington, DC.

United States Senate (1983) Las Vegas Paiute tribe trust lands. Hearing before the select committee on Indian affairs. Ninety-eighth Congress, First Session, on S. 1694. US Government Printing Office, Washington, DC.

UNLV (University of Nevada, Las Vegas) (n.d.) UNLV map archive [WWW document]. URL http://digital.library .unlv.edu/collections/maps/ (accessed 9 September 2013). 
Venturi, R. (1996) Iconography and electronics upon a generic architecture: a view from the drafting room. MIT Press, Cambridge, MA.

Venturi, R. and D. Scott Brown (1968) A significance for A\&P parking lots, or learning from Las Vegas. Architectural Forum March, 37-43.

Venturi, R. and D. Scott Brown (1996) Las Vegas after its classic age. In R. Venturi (ed.), Iconography and electronics upon a generic architecture: a view from the drafting room. MIT Press, Cambridge, MA.
Venturi, R., D. Scott Brown and S. Izenour (1972) Learning from Las Vegas. MIT Press, Cambridge, MA.

Venturi, R., D. Scott Brown and S. Izenour (1977) Learning from Las Vegas. Revised edition, MIT Press, Cambridge, MA.

Wallerstein, I. (2003) The decline of American power. New Press, New York.

Zook, L.M., A. Sandquist and C. Burke (2009) Las Vegas 1905-1965. Arcadia Publishing, Charleston, SC. 